\title{
Research Article \\ Formulation and Evaluation of Solid Dispersion Chitosan Tablet from Whiteleg Shrimp (Litopenaeus vannamei) Using PVP K-30 As a Carriers
}

Hilya Nur Imtihani* ${ }^{*}$
Fitria Abbas Thalib
Silfiana Nisa Permatasari
Department of Pharmacy, Akademi
Farmasi Surabaya, Surabaya, East Java,
Indonesia
*email: hilya.imtihani@gmail.com
Keywords:
Chitosan
PVP K-30
Solid dispersion
Tablet
Whiteleg shrimp

\begin{abstract}
Whiteleg shrimp (Litopenaeus vannamei) on the market are processed or sold only to take part in the meat. The head, shell, and tail are thrown away without any prior processing. Underutilized waste causes environmental problems. An alternative to overcome this environmental disturbance phenomenon is to utilize shrimp shells containing chitin and subsequently transformed into chitosan that can be applied in various fields. Chitosan has poor solubility in water but high permeability; thus, improve bioavailability is accomplished by making solid dispersions. This study aims to formulate and evaluate the solid dispersion tablet using chitosan extract from L. vannamei as an active agent with PVP K-30 as a carrier. The formulation divided into three groups, that was F1 (chitosan : PVP K-30 = $1: 1$ solid dispersion), F2 (chitosan : PVP K-30 = 1: 3 solid dispersion), and F3 (pure chitosan). The result of chitosan solid dispersion was molded into tablets by the direct compression method. The tablets were evaluated by weight and size uniformity, hardness, friability, and disintegration time. All the formulas by weight and size uniformity as well as disintegration time fulfill the requirements. The hardness of the tablets from F3 with 4,275 kg was the best from F1 and F2. By statistic analytical from weight uniformity, hardness and disintegration time give significant difference with sig. $<0.05$.
\end{abstract}

Received: July 23rd, 2020

Accepted: November 24th 2020

Published: February 28th, 2021

(C) 2021 Hilya Nur Imtihani, Fitria Abbas Thalib, Silfiana Nisa Permatasari. Published by Institute for Research and Community Services Universitas Muhammadiyah Palangkaraya. This is an Open Access article under the CC-BYSA License (http://creativecommons.org/licenses/by-sa/4.0/). DOI: https://doi.org/10.33084/bjop.v4i1.1557

\section{INTRODUCTION}

Indonesia is a maritime country with considerable potential as a producer of marine animals, primarily natural sources of chitin, such as shrimp and crab shells ${ }^{1}$. Shrimp shell contains $25-40 \%$ protein, $45-50 \%$ calcium carbonate, and $15-30 \%$ chitin, but the amount of the content depends on the type of shrimp ${ }^{2}$. In this study, chitin was extracted from whiteleg shrimp (Litopenaeus vannamei) because it was ranked first of the five primary commodities trafficked in the country (between provinces) as much as $72.81 \%$. This fact means that a lot of shrimp production has been distributed to regions between provinces. East Java is the second-highest province after Bengkulu (37.84\%) as an L. vannamei supplier with $24.49 \%{ }^{3}$. However, chitin is not soluble in water, so its use is limited. By using a strong base (deacetylation process) into chitosan, hydrolyzing chitin has better chemical properties ${ }^{4}$

Chitin can be transformed into chitosan, which has prospects in biomedical trends ${ }^{5}$. Besides being known as a drug carrier, chitosan is also known as an active agent for anticholesterol. The previous research reported that in vitro, chitosan could bind cholesterol by $63.5 \%$ to prevent an increase in cholesterol levels ${ }^{6}$. A study stated that administering 30 chitosan tablets at a dose of $45 \mathrm{mg}$ of chitosan/tablet three times a day can reduced cholesterol 
levels 7 . However, chitosan has poor solubility in water, but the permeability is high, so efforts are needed to increase the solubility so that chitosan can be used as an anticholesterol drug.

Solid dispersion is a method of making a dispersion system where drugs with low solubility in water will be dispersed into a water-soluble carrier to increase the solubility and dissolution of the drug8,9. The carrier used in this solid dispersion formulations is PVP K-30 because its polymer is hydrophilic, has very good water solubility, and can be used as a stabilizer ${ }^{10}$. The results of the chitosan solid dispersion formulation were hence made into direct compression tablets. The direct compression method was chosen because it is the most energy-efficient, fastest, and most economical way to produce tablets ${ }^{11}$. Based on this background, research will be carried out to formulate and evaluate the solid dispersion tablet using chitosan extract from $L$. vannamei as an active agent with PVP K-30 as a carrier in the ratio of $1: 1$ and 1:3 (Chitosan: PVPK-30). Evaluation of solid dispersion tablets is weight and size uniformity, hardness, friability, and disintegration time.

\section{MATERIALS AND METHODS}

\section{Materials}

The L. vannamei was obtained from Pasuruan, East Java. The reagents used include $\mathrm{HCl}$ (Merck), $\mathrm{NaOH}$ (Merck), ninhydrin solution, distilled water (Brataco), PVP K-30 (Merck), magnesium stearate, talk, and Avicel PH 102 (Mingtai).

\section{Methods}

\section{Chitosan synthesis}

1. Pre-treatment: The shell of L. vannamei was washed with running water and boiled for 15 minutes. The clean shell dried in the sunlight for $2 \times 24$ hours or until dry. The dried shell was blended with a blender until smooth and sieved with 100 mesh $^{12}$.
2. Demineralization: $100 \mathrm{~g}$ of the sifted shell of $L$. vannamei powder was weighed. $1 \mathrm{M} \mathrm{HCl}$ solution was added while stirring with a magnetic stirrer with a speed of $200 \mathrm{rpm}$ at $75^{\circ} \mathrm{C}$ for an hour. The solution was filtered with filter paper, and rinse the residue with distilled water until neutral $\mathrm{pH}$. The residue was dried in the oven at $60^{\circ} \mathrm{C}$ for 24 hours or until it dries ${ }^{12}$.

3. Deproteination: The dry solids demineralized were dissolved in $3.5 \% \mathrm{NaOH}$ while stirring with a magnetic stirrer speed of $450 \mathrm{rpm}$ at $65^{\circ} \mathrm{C}$ for 2 hours. The mixed solution was filtered with filter paper, and the residue was rinsed with distilled water until neutral $\mathrm{pH}$. The residue was dried in the oven at $65^{\circ} \mathrm{C}$ for 24 hours or until it dries ${ }^{13}$.

4. Deacetylation: Chitin from the deproteination was dissolved in $60 \% \mathrm{NaOH}$ with ratio of $1: 20(\mathrm{w} / \mathrm{v})$. The solution was stirred using a magnetic stirrer with 250 rpm at $100^{\circ} \mathrm{C}$ for 4 hours. The mixed solution was filtered with filter paper. The residue was rinsed with distilled water until neutral $\mathrm{pH}$ and dried in an oven at $65^{\circ} \mathrm{C}$ for 24 hours or until it dries ${ }^{13,14}$.

\section{Chitosan evaluation}

Chitosan from synthesis was evaluated by organoleptic, yield, ninhydrin, and deacetylation degrees ${ }^{15,16}$.

\section{Solid dispersion procedure}

Chitosan and PVP K-30 was prepared in a ratio of $1: 1$ and $1: 3(\mathrm{w} / \mathrm{w})$. Chitosan was dissolved in $2 \%$ acetic acid (1: 50) and stirred until it dissolves. PVP K-30 as a carrier was dissolved in (1:5) of $2 \%$ acetic acid solvent. Both solutions were mixed and evaporated above the water bath in a fume hood at $50-60^{\circ} \mathrm{C}$ until a precipitate was formed. The evaporation results were dried in the oven at $50^{\circ} \mathrm{C}$ for $1-2$ hours or until it dries. The masses were crusted and sieved with 100 mesh sieves ${ }^{17}$.

\section{Tablets formulation}

Chitosan and PVP K-30 solid dispersion were prepared as well as weighed magnesium stearate, talk, and Avicel 
PH 102 which was sieved with a mesh 100 sieve. That ingredient was mixed until homogeneous. Therefore, the tablets were compressed by the direct compression method. The tablets were observed and evaluated (uniformity in tablet weight and size, hardness, friability, and disintegration time $)^{18}$.

\section{Experimental design}

The dose of chitosan as an active pharmaceutical ingredient (API) was $45 \mathrm{mg}$ / tablet by the study of Jing et

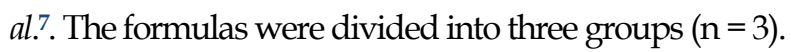
The division of groups was arranged based on different materials as follows:

1. F1 (control): Pristine chitosan as an active agent

2. F2: Chitosan : PVPK-30 solid dispersion (1:1) $(\mathrm{w} / \mathrm{w})$.

3. F3: Chitosan : PVPK-30 solid dispersion $(1: 3)$ (w/w).

\section{RESULTS AND DISCUSSION}

The formulation of solid dispersion tablets of chitosan extract from L. vannamei shell with PVP K-30 as a carrier of solid dispersion started with chitosan synthesis. From these stages, the chitosan obtained was then evaluated. The evaluation results were presented in Table I, while the chitosan powder appearance was presented in Figure 1.

Table I. Result of chitosan characterization from L. vannamei shell

\begin{tabular}{|c|c|c|c|}
\hline Parameter & $\begin{array}{c}\text { Chitosan } \\
\text { characterization }\end{array}$ & Result & Interpretation \\
\hline Shape & $\begin{array}{l}\text { Flakes to } \\
\text { powder }\end{array}$ & Powder & Good \\
\hline Color & $\begin{array}{l}\text { Light brown to } \\
\text { white }\end{array}$ & $\begin{array}{l}\text { Creamy } \\
\text { white }\end{array}$ & Good \\
\hline $\begin{array}{l}\text { Deacetylation } \\
\text { degree }\end{array}$ & $<70 \%$ & $74.02 \%$ & Good \\
\hline Ninhydrin & $\begin{array}{c}(+) \\
\text { Changes to } \\
\text { purple }\end{array}$ & $\begin{array}{c}(+) \\
\text { Changes to } \\
\text { purple }\end{array}$ & Good \\
\hline Yield & - & $16.21 \%$ & - \\
\hline
\end{tabular}

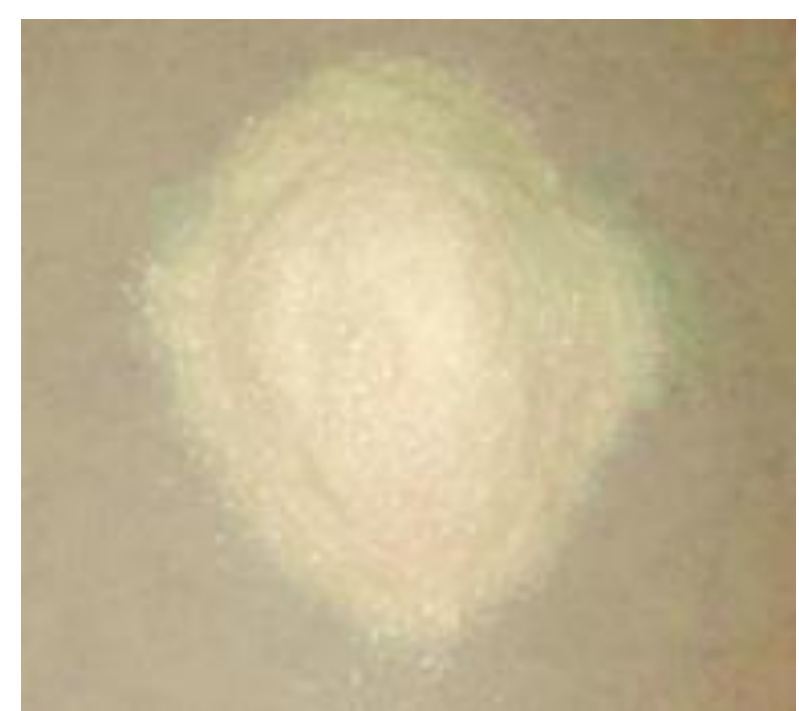

Figure 1. Chitosan powder F1

From the evaluation of chitosan, it could be stated that chitosan had fulfilled all the evaluation requirements that exist from organoleptic (shape and color) which was creamy white ${ }^{19}$, deacetylation degree with $74.02 \%$ $(>70 \%)^{20}$, and ninhydrin test with positive purple ${ }^{6}$. The yield test was a chitosan recovery test compared to the amount of shrimp shell used. The yield test result was $16.21 \%$, which was higher than the previous research result which was $15.26 \% .^{21}$.

Hence, the chitosan was made into a solid dispersion system to increase chitosan solubility, except for F1 as control, and then formulated into tablet preparations as showed in Table II. The direct compression method carried out the tablet formulation and used additional ingredients to formulate the direct compression tablet method with good flow and compactibility, as shown in Figure 2.

\begin{tabular}{lcccc} 
Table II. & \multicolumn{5}{c}{ Formulation of solid dispersion tablet chitosan } \\
\hline Material & Use & F1 (control) & F2 (1:1) & F3 (1:3) \\
\hline Chitosan & $\begin{array}{l}\text { Active } \\
\text { agent }\end{array}$ & $45 \mathrm{mg}$ & $45 \mathrm{mg}$ & $45 \mathrm{mg}$ \\
$\begin{array}{l}\text { PVPK- } \\
30\end{array}$ & Carrier & - & $45 \mathrm{mg}$ & $135 \mathrm{mg}$ \\
$\begin{array}{l}\text { Mg } \\
\text { Stearate } \\
\text { Talk }\end{array}$ & Lubricant & $1 \%$ & $1 \%$ & $1 \%$ \\
$\begin{array}{l}\text { Avicel } \\
\text { PH102 }\end{array}$ & Dilidant & $2 \%$ & $2 \%$ & $2 \%$ \\
\hline
\end{tabular}




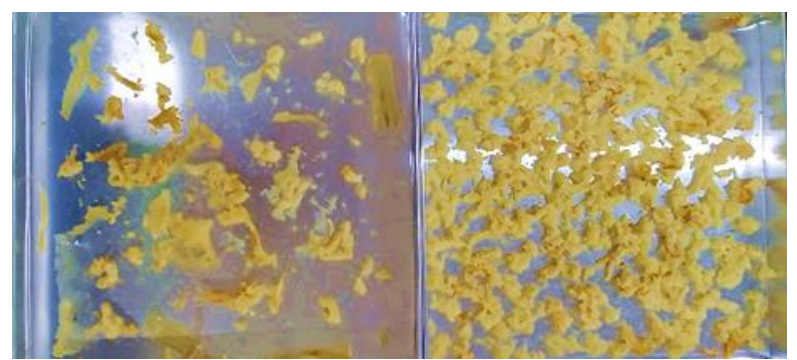

Figure 2. Solid dispersion of F2 (left) and F3 (right)

Evaluation of dispersion tablet started with weight uniformity. The result from this evaluation was all three formulas had good uniformity and none of the tablets out from $\mathrm{A}$ and $\mathrm{B}$ column ${ }^{18}$. The statistical analysis with oneway ANOVA shows that sig. 0,000. Moreover, the LSD (Least Significant Difference) shows that F2 and F3 significantly different from F1. Therefore, a solid dispersion tablet made an impact on chitosan without solid dispersion making.

The uniformity size from F1, F2, and F3 fulfill the requirements ${ }^{18}$, which was $1 / 3 \mathrm{~T}<\mathrm{D}<3 \mathrm{~T}$. $\mathrm{T}$ was the thickness, and D was the diameter. F1 was $1.25<11.14<$ 11.25; F2 was $1.27<11.29<11.40$; and F3 was $1.27<11.09$ $<11.40$. The statistical analysis with Kruskal-Wallis from diameter shows that asymp. Sig. 0.000. Furthermore, Mann-Whitney Test shows that all the formulas had significantly different from each other. However, the Levene Test's statistical analysis from tablet thickness shows that the result was not significantly different from each other.

The tablets were also tested using the hardness tester. The requirement for tablet hardness was $4-8 \mathrm{~kg}^{22}$. The average hardness from F1 was $1.975 \pm 0.444 \mathrm{~kg}$; F2 was $1.175 \pm$ $0.494 \mathrm{~kg}$; and F3 was $4.275 \pm 1.482 \mathrm{~kg}$. It shows that $\mathrm{F} 3$ was the best hardness character and the one hardness that fills requirements ${ }^{22}$. F3 was chitosan without made solid dispersion. Development formula from direct compression tablets was required to generate good hardness tablet quality. The statistical analysis with Kruskal-Wallis from the hardness test shows that asymp.
Sig. 0.000. Moreover, Mann-Whitney Test shows that all the formulas had significantly different from each other. The tablet friability from all formulas was not too good. The requirements were $<1 \% 23$, while F1 friability was $6.05 \%$, F2 was $46.25 \%$, and F3 was $1.44 \%$. Necessarily, formula development made the tablet more compact and had a good binding, so it was not too weak and brittle. Wet granulation could be considered to made better compactibility because the wet granulation method made intragranular bonding (formed during granule drying) that did not seem broken during compression, the cohesion of particles and binders carrier-binding adhesion was a type of bond that contributes to the strength of the tablet ${ }^{11}$.

The last evaluation was disintegration time. The requirement of disintegration time was no more than 15 minutes $^{18}$. The result for F1 was $4.33 \pm 0.819$ s; F2 was $20.67 \pm 2.33$ s; and F3 was $33.17 \pm 9.43$ s. The tablets had so fast disintegration time because the friability was weak and did not fill the requirements. Necessarily, formula development made the tablet more compact and had a good binding, not too weak and brittle. The statistical analysis with Kruskal-Wallis from disintegration time shows that asymp. Sig. 0.001. Furthermore, by MannWhitney Test show that all the formulas had significantly different from each other. The overall results of the evaluation and characterization were presented in Table III.

Table III. Result of solid dispersion chitosan tablet characterization

\begin{tabular}{lccc}
\hline $\begin{array}{c}\text { Characteristic } \\
\text { tablet }\end{array}$ & F 1 & F2 & F3 \\
\hline Diameter (mm) & $11.14 \pm$ & $11.29 \pm$ & $11.09 \pm$ \\
& 0.046 & 0.255 & 0.040 \\
Thickness (mm) & $3.75 \pm 0.415$ & $3.80 \pm 0.474$ & $3.80 \pm 0.394$ \\
& & & \\
Weight variation & $0.3575 \pm$ & $0.3435 \pm$ & $0.3480 \pm$ \\
(g) & 0.010 & 0.007 & 0.006 \\
Hardness & $1.98 \pm 0.44$ & $1.18 \pm 0.49$ & $4.28 \pm 1.48$ \\
(kg) & & & \\
Friability & 6.05 & 46.26 & 1.44 \\
(\%) & & & \\
Disintegration & $4.33 \pm 0.82$ & $20.67 \pm 2.34$ & $33.17 \pm 9.43$ \\
time (s) & & & \\
\hline
\end{tabular}


The direct compression method had the limitation that could ensue segregation and poor compressibility compared to the wet granulation method. Differences in density between materials could cause segregation ${ }^{24}$. That could also cause the evaluation of hardness and friability in this study to be unfavorable. Further method development was needed to provide better research, such as using the wet granulation method.

\section{CONCLUSION}

In conclusion, Formula F1, F2, and F3 meet the requirements for uniformity of weight and size as well as disintegration time. The hardness of $\mathrm{F} 3$ is better than $\mathrm{F} 1$ and F2. Statistical analysis from weight uniformity, hardness, and disintegration time give a significant difference-obligatory formulation developing to make better tablet's compactibility.

\section{ACKNOWLEDGMENT}

The authors would like to thank for financial support from LLDIKTI Wilayah VII Kementerian Pendidikan dan Kebudayaan for research grants Penelitian Dosen Pemula No. 083/SP2H/LT/DRPM/2020, 9 March 2020; 145/SP2H/LT-MONO/LL7/2020, 17 March 2020; 061/AKFAR-SBY/LPPM/70.03/III/2020, 30 March 2020, and for Research Internal Grant 2020 from Akademi Farmasi Surabaya.

\section{REFERENCES}

1. Elieh-Ali-Komi D, Hamblin MR. Chitin and Chitosan: Production and Application of Versatile Biomedical Nanomaterials. Int J Adv Res. 2016;4(3):411-27.

2. Khoushab F, Yamabhai M. Chitin Research Revisited. Mar Drugs. 2010;8(7):1988-2012. doi:10.3390/md8071988

3. Badan Karantina Ikan, Pengendalian Mutu dan Keamanan Hasil Perikanan. Peta Lalulintas Benih
Ikan dan Benur Udang Nasional 2018 [Internet]. Jakarta, Indonesia: Badan Karantina Ikan, Pengendalian Mutu dan Keamanan Hasil Perikanan; 2018 [updated 2018; cited 2020 Jul 23]. Available from: https://kkp.go.id/bkipm/artikel/5880-petalalulintas-benih-ikan-dan-benur-udang-nasional2018

4. Santos VP, Marques NSS, Maia PCSV, de Lima MAB, Franco LO, de Campos-Takaki GM. Seafood Waste as Attractive Source of Chitin and Chitosan Production and Their Applications. Int J Mol Sci. 2020;21(12):4290. doi:10.3390/ijms21124290

5. Kurakula M, Raghavendra NN. Prospection of recent chitosan biomedical trends: Evidence from patent analysis (2009-2020). Int J Biol Macromol. 2020;165(B):1924-38. doi:10.1016/j.ijbiomac.2020.10.043

6. Ylitalo R, LehtinenS, Wuolijoki E, Ylitalo P, Lehtimäki T. Cholesterol-lowering properties and safety of chitosan. Arzneimittelforschung. 2002;52(1):1-7. doi:10.1055/s-0031-1299848

7. Jing SB, Li L, Ji D, Takiguchi Y, Yamaguchi T. Effect of chitosan on renal function in patients with chronic renal failure. J Pharm Pharmacol. 1997;49(7):721-3. doi:10.1111/j.2042-7158.1997.tb06099.x

8. Wardiyah, Asyarie S, Wikarsa S. Pembuatan dan Karakterisasi Dispersi Padat Sistem Biner dan Terner dari Gliklazid. Acta Pharm Indo. 2012;37(3):95-101.

9. Vasconcelos T, Sarmento B, Costa P. Solid dispersions as strategy to improve oral bioavailability of poor water soluble drugs. Drug Discov Today. 2007;12(2324):1068-75. doi:10.1016/j.drudis.2007.09.005

10. Rowe RC, Sheskey PJ, Owen SC. Handbook of Pharmaceutical Excipients. $6^{\text {th }}$ edition. Michigan, US: Pharmaceutical Press; 2009.

11. Siregar EC, Suryati S, Hakim L. Pengaruh Suhu dan Waktu Reaksi pada Pembuatan Kitosan dari Tulang Sotong (Sepia officinalis). Jurnal Teknologi Kimia Unimal. 2016;5(2):37-44. doi:10.29103/jtku.v5i2.88

12. Agustina S, Swantara IMD, Suartha IN. Isolasi Kitin, Karakterisasi, dan Sintesis Kitosan dari Kulit Udang. Jurnal Kimia J Chem. 2015;9(2):271-8. doi:10.24843/JCHEM.2015.v09.i02.p19

13. Harjanti RS. Kitosan dari Limbah Udang sebagai Bahan Pengawet Ayam Goreng. Jurnal Rekayasa Proses. 2014;8(1):12-9. doi:10.22146/jrekpros.5018 
14. Khan TA, Peh KK, Ch'ng HS. Reporting degree of deacetylation values of chitosan: the influence of analytical methods. J Pharm Pharm Sci. 2002;5(3):20512.

15. Tokatli K, Demirdöven A. Optimization of chitin and chitosan production from shrimp wastes and characterization. J Food Process Preserv. 2017;42(2): e13494. doi:10.1111/jfpp.13494

16. Hossain MS, Iqbal A. Production and characterization of chitosan from shrimp waste. J Bangladesh Agril Univ. 2014;12(1):153-60. doi:10.3329/jbau.v12i1.21405

17. Zaini E, Novitasari N, Octavia MD. Pembentukan Sistem Dispersi Padat Amorf Azitromisin Dihidrat dengan Hikroksipropil Metilselulosa (HPMC). JSFK Jurnal Sains Farmasi \& Klinis. 2017;3(2):165-71. doi:10.29208/jsfk.2017.3.2.140

18. Ministry of Health of the Republic of Indonesia. Farmakope Indonesia Edisi V. Jakarta, Indonesia: Ministry of Health of the Republic of Indonesia; 2014.

19. Yanti R, Drastinawati D, Yusnimar Y. Sintesis Kitosan Dari Limbah Cangkang Kepiting Dengan Variasi Suhu Dan Waktu Pada Proses Deasetilasi. JOM FT Universitas Riau. 2018;5(2):1-7.

20. Dompeipen EJ, Kaimudin M, Dewa RP. Isolasi Kitin dan Kitosan dari Limbah Kulit Udang. Majalah BIAM. 2016;12(1):32-9. doi:10.29360/mb.v12i1.2326

21. Zahiruddin W, Ariesta A, Salamah E. Characteristics of Quality and Solubility Kitosan From Head of Shrimp (Penaeus Monodon) Silase Dregs. Jurnal Pengolahan Hasil Perikanan Indonesia. 2008;11(2):259. doi:10.17844/jphpi.v11i2.917

22. Lachman L, Lieberman HA, Kanig JL. Teori dan Praktek Industri Farmasi. 3rd edition. Jakarta, Indonesia: Universitas Indonesia Press; 2008.

23. Fuhrman Jr LC. Ansel's Pharmaceutical Dosage Forms and Drug Delivery Systems, $8^{\text {th }}$ Edition. Am J Pharm Educ. 2006;70(3):71.

24. Iqubal MK. Recent Advances in Direct Compression Technique for Pharmaceutical Tablet Formulation. Int J Pharm Res Dev. 2014;6(1):49-57. 